\title{
Development of a Marketing Strategy for Enterprise Financial Growth
}

\author{
OLENA LABURTSEVA ${ }^{1}$, YAROSLAVA LARINA ${ }^{2}$, OLENA NAHORNA ${ }^{3}$, SERHII VINICHENKO ${ }^{4}$, \\ VIKTORIIA HORDIIENKO ${ }^{5}$, ALAA TABIT NIAMA AL-SHABAN ${ }^{6}$ \\ ${ }^{1}$ Department of Marketing, Kyiv National University of Trade and Economics \\ ${ }^{2}$ Department of Marketing named after A.F. Pavlenko, KYIV NATIONAL ECONOMIC UNIVERSITY NAMED AFTER \\ VADYM HETMAN, UKRAINE. E-mail: ttt_lag@ukr.net \\ 3,4,6 Department of Marketing and International Trade, NATIONAL UNIVERSITY OF LIFE AND ENVIRONMENTAL \\ SCIENCES OF UKRAINE, UKRAINE. \\ ${ }^{5}$ Department of Economics and Entrepreneurship, ODESSA STATE ACADEMY OF CIVIL ENGINEERING AND \\ ARCHITECTURE, UKRAINE.
}

\begin{abstract}
The development of marketing strategies has long been engaged in by scientists and practitioners who have written countless algorithms, mechanisms and schemes for the successful development of a marketing strategy. However, in current conditions, all these developments have become obsolete for one main reason: the behaviour of the buyer has radically changed. This reason has again raised the need to develop effective recommendations for the formation of a marketing strategy for the enterprise's financial growth. The authors analyzed the main aspects of strategic planning, studied the features of the leading marketing strategies. The development of a marketing strategy for an enterprise follows almost the same scheme; however, the study showed that customers had changed dramatically: first of all, they are interested in the personal attitude, and only then in the quality of the goods, the price - the usual indicators that have always been in the first places. Taking into account the changed vector, the authors adapted the algorithm for developing a marketing strategy for the financial growth of an enterprise and tested the operation of one of the proposed tools on a real example, which showed its effectiveness in current conditions.
\end{abstract}

Keywords: financial growth, influencer, marketing strategy, Net Marketing Contribution.

JEL Classification: G40, M31, O40 


\section{Introduction.}

In current economic conditions, the problem of choosing the priority areas of economic development of financial entities is one of the most critical tasks, the solution of which is primarily due to a high degree of uncertainty in long-term trends in the development of the national economy, limited financial, information and organizational capabilities. The formation of a strategy for the economic growth of an enterprise focused on the long term is a reliable basis for its survival in a challenging competitive environment and should proceed from the final results of production, taking into account the needs of the market, the prevailing features of the production process, style and management methods, the level of organizational culture. The informed choice of marketing strategies will influence the formation of strategic success factors.

In order to adapt to them and choose a method of market behaviour that provides an enterprise with an advantageous position not only at the moment but also for the future, it is necessary to define its own vision, goals and objectives, competitive positioning, target markets and segments.

\section{The theoretical basis for the development of marketing strategy for the enterprise's financial growth.}

\subsection{Features of a strategic approach in formation of marketing activities.}

A marketing strategy is a set of long-term decisions regarding ways to meet the needs of existing and potential customers of an enterprise by using its internal resources and external capabilities. The marketing strategy of an enterprise is usually fixed in a document bearing the same name or the name "marketing policy" and is developed as an integral part of the overall development strategy of the enterprise [1-2]. Depending on the industry, the market situation and the prevailing features of the organization's management, the marketing strategy can be developed for a period from 1 to 25 years.

It should be noted that the development of a marketing strategy is based on strategic analysis and forecast of the market potential of an enterprise as a dynamic characteristic, which combines production, technological and marketing capabilities [3-4]. An essential element of this analysis is determining the starting and potential positions of the enterprise in the competitive struggle in the target market. Based on this analysis, entire enterprises are formed, and strategies for their achievement are selected.

In addition, marketing activities should always be strategic in nature (Fig. 1).

It is important to learn to distinguish between strategic and tactical ideas, understand the difference between operational and strategic marketing, the corresponding goals and objectives, and see the relationship between them. Operational marketing is the active side of marketing, a dynamic process, targeted actions and operations. Strategic marketing is the analytical side of marketing, an analytical process, that is, the logic and comprehension of goals.

The role of strategic marketing is to target the enterprise at attractive strategic opportunities, adapted to its resources and know-how (trade secrets), providing the potential for growth and profitability. 
Figure 1. Features of a strategic approach to the formation of marketing activities

\begin{tabular}{|c|c|}
\hline $\begin{array}{l}\text { Strategic } \\
\text { marketing }\end{array}$ & $\begin{array}{l}\text { is a long-term success study of the market opportunities and capabilities } \\
\text { of an enterprise, leading to the development of appropriate marketing } \\
\text { strategies and tactics for the target segments. }\end{array}$ \\
\hline $\begin{array}{l}\text { BENEFITS } \\
\text { - to direct the } e \\
\text { - coordinate the }\end{array}$ & $\begin{array}{l}\text { ise with passive adaptation to market requirements to their active formation; } \\
\text { areas of the enterprise, directing their action to specific, long-term work with consumers; }\end{array}$ \\
\hline $\begin{array}{l}\text { PRINCIPLES } \\
\text { - mutual agr } \\
\text { - based on cc } \\
\text { - cyclicality, } \\
\text { - flexibility, } \\
\text { - multivarian }\end{array}$ & $\begin{array}{l}\text { with the overall strategic planning of the enterprise; } \\
\text { ous research of the marketing environment; } \\
\text { foresees the need for marketing planning as an uninterrupted process; } \\
\text { neans constant marketing strategy adaptation to changes in the marketing environment; } \\
\text { ich foresees taking into account possible environmental changes in different variants of the }\end{array}$ \\
\hline $\begin{array}{l}\text { TASKS } \\
\text { 1) setting str } \\
\text { plans; } \\
\text { 2) assessmen } \\
\text { 3) developme } \\
\text { 4) developme } \\
\text { 5) developme } \\
\text { 6) preparatio } \\
\text { 7) forming lo } \\
\text { 8) creating cc } \\
\text { 9) providing }\end{array}$ & $\begin{array}{l}\text { marketing goals for specific products and markets; 2) development of marketing strategies and } \\
\text { e attractiveness of markets, the capabilities and competencies of the company; } \\
\text { a segmentation strategy for selected markets; } \\
\text { strategy for competing in target segments; } \\
\text { strategy for positioning a product, brand, company in target segments; } \\
\text { rategic decisions on "4P" for the development of target segments; } \\
m \text { relationships with customers; } \\
\text { tive offers and a strong trademark, brand; } \\
\text { o customers and promoting value; }\end{array}$ \\
\hline
\end{tabular}

(source: compiled by the authors based on $[1 ; 2 ; 4]$ )

\subsection{Classification of marketing strategies.}

Roger Best identified six main marketing strategies shown in Fig. 2.

Figure 2. Main marketing strategies by R. Best [5]

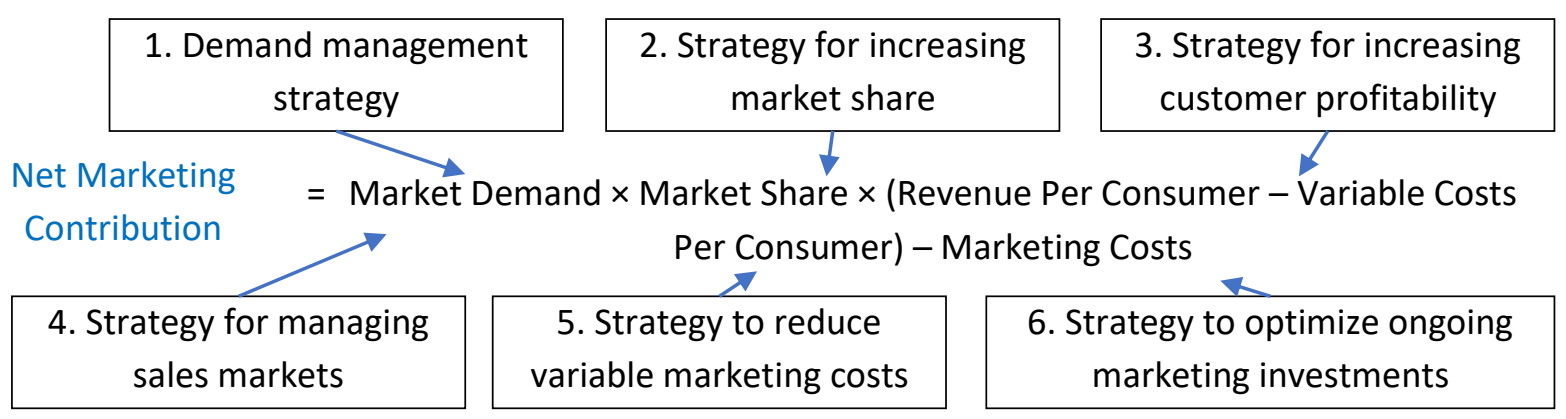

1. Demand management strategy. The division of marketing tasks depending on the state of demand and the characteristics of types of management are shown in Fig. 3. In the case of full demand, this strategy's choice is not justified, since this situation is typical for stable systems. So, for anti-crisis management, such a strategy is justified in the event of negative, absent, potential, declining, fluctuating, excessive or irrational demand. In arbitration management, this strategy can be chosen in case of negative or absent demand. The projected discounted cash flow of the selected strategy must be equal to or higher than the current indicator for implementing decisions within this strategy. 
Figure 3. Marketing tasks depending on the state of demand

\begin{tabular}{|c|c|c|}
\hline State of demand & Type of management & Marketing tasks \\
Negative demand & Create demand \\
Lack of demand & $\begin{array}{c}\text { Anti-crisis, arbitration } \\
\text { management }\end{array}$ & Stimulate demand \\
Potential demand & $\begin{array}{c}\text { Ordinary, anti-crisis } \\
\text { management }\end{array}$ & Develop demand \\
Decline in demand & Increase demand \\
Fluctuating demand & Crisis management & Balance demand \\
Full demand & Ordinary management & Maintain demand \\
Excessive demand & Anti-crisis, ordinary & Reduce demand \\
Irrational demand & management & Eliminate demand
\end{tabular}

(source: compiled by the authors based on [6])

2. Strategies for increasing market share. The most common marketing strategy for the financial growth of an enterprise is market share growth. To improve profitability, the NMC in the penetration strategy needs to exceed its current NMC value. If the organization is unable to increase its market share, it is recommended to apply the "blue ocean" strategy proposed by W. Chan Kim and Renee Mauborgne [7]. The strategy's essence lies in the fragmentation of the market in which the organization operates, mixing it with alternative industries based on the value chain of current or potential customers.

3. Strategy for increasing customer profitability. The strategy is aimed at optimizing the client portfolio. Within the framework of the approach, it is advisable to single out groups of buyers by their average check or frequency of purchases and focus the main forces on more profitable segments. The current strategy works most effectively when combined with a strategy to reduce variable costs per customer.

4. Strategies for managing sales markets. This approach is often associated with strategy 1 "Demand Management Strategy" and implies the expansion or contraction of sales markets. For the purposes of managing unstable systems, the fastest, cheapest, and most risk-free way is the strategy of returning an organization or brand to the market with a previously known product (service). This strategy is usually used at the first stages of anti-crisis measures, and if competitors do not yet occupy the niche. Another anti-crisis strategy in the framework of sales markets management is the strategy of developing a product or service, including the blue ocean strategy described in the second strategy. Its implementation is considered costly; therefore, it is carried out to access external financing. Speaking about the strategy's performance in the context of arbitration management is necessary to consider its application as a somewhat risky step, but often the only possible one within the framework of the financial recovery procedure. It should be remembered that the reduction of one product line may affect the rest's efficiency, and it is necessary to calculate in advance the impact of such decisions on the business as a whole. This lies in the fact that fixed costs are proportional to all types of products produced. That is, the closure of the production of one or several commodity items may lead to a possible reallocation of fixed costs and a revision of prices, which may turn out to be higher than market prices and may contribute to a more considerable drop in sales.

5. Strategies to reduce variable marketing costs. Another way to increase your bottom line is to reduce variable costs. This strategy will increase margins per unit of product, but for medium and long-term organizational performance, do not forget about customer satisfaction indicators.

6. Strategies to optimize ongoing marketing investments. This strategy is most obvious in an unstable state when the organization enters an economy mode. As part of the strategy, costs not related to distribution and customer service are reduced, primarily budgets for non-core research, 
media budgets in the event of their possible cancellation without fines within media transactions, budgets for sponsorship events, etc.

The marketing management approach based on the NMC indicator is a fairly simple and effective way that shows the relationship of marketing tools with marketing performance indicators, measured quantitatively (in money), which is especially important when generating a marketing report to the company's management and shareholders. The disadvantage of this approach is that it does not consider such financial indicators as the degree of solvency, increasing the profitability of sales, which affects the organization's uneven development. When managing marketing based on the choice of such strategies, it is not always obvious which marketing tools were able to influence the financial result, and whether it was possible to increase financial stability at all.

For a more financially oriented marketing approach in management, it is necessary to consider the relationship between marketing and financial indicators.

\subsection{Algorithm for developing an enterprise marketing strategy.}

A marketing strategy should be developed in accordance with the goals and plans of the enterprise; thus, a marketing plan should be developed for it.

Figure 4. The process of developing a marketing strategy

\begin{tabular}{|c|c|c|}
\hline \multicolumn{3}{|c|}{$\begin{array}{l}\text { Step 1. Analysis of the situation } \\
\text { An in-depth analysis of market forces, the competitive position of the enterprise and the } \\
\text { results achieved }\end{array}$} \\
\hline \multicolumn{3}{|l|}{$\begin{array}{l}\text { Step 2. Swot analysis } \\
\text { es, opportunities, and ri }\end{array}$} \\
\hline \multicolumn{3}{|l|}{ Step 3. Strategic $p$} \\
\hline $\begin{array}{l}\text { Step 4. Detailed marketing strategy } \\
\text { Based on a specific strategic plan, a list of marketing tools is formed wit } \\
\text { which the company will be able to achieve its goals. }\end{array}$ & he help of & \\
\hline $\begin{array}{l}\text { Step } 5 \text { Marketing budget } \\
\text { To implement a specific marketing strategy, the budget must include } \\
\text { resources with which the company will be able to fulfil its strategic }\end{array}$ & $\begin{array}{l}\text { lecessary } \\
\text { ctives. }\end{array}$ & \\
\hline $\begin{array}{l}\text { Step } 6 \text { Forecast of implementation } \\
\text { The forecast for marketing and operational results is created over the y } \\
\text { year perspective. }\end{array}$ & for a 3-5- & \\
\hline $\begin{array}{l}\text { Step 7. Evaluation of the result } \\
\text { Whether the business will be able to achieve the desired results (target } \\
\text { market share, revenue and profit) through the marketing strategy. }\end{array}$ & $\stackrel{\text { no }}{\longrightarrow} \begin{array}{l}\text { the discrep } \\
\text { the plan a } \\
\text { situation is } \\
\text { and requ }\end{array}$ & \\
\hline
\end{tabular}

The marketing plan contains criteria for evaluating both the marketing strategy itself and the company's activities as a whole, as well as a forecast for changes in the company's market share, a forecast of revenue and profit for a certain period. It may seem that developing a plan is not such a difficult task, but the business environment is complex, and many factors affect the market situation, strategy and resources required at a particular moment. The market situation components are constantly changing - the needs of consumers, the structure and strategy of competitors, the 
operating environment. In addition, the company almost never has complete and accurate market information.

Already, a lot of instructions have been developed for drawing up marketing plans and marketing strategies $[1 ; 5 ; 8-12]$. They are different, take into account various factors, but they have a common core. Adapting to the object of research, we present the algorithm in this form (Fig. 4).

The development of marketing strategies has long been engaged in by scientists and practitioners who have written countless algorithms, mechanisms, and schemes to develop a marketing strategy. However, in current conditions, all these developments have become obsolete for one main reason: the buyer's behaviour has radically changed (Fig. 5).

Figure 5. Reasons for refusal of clients from services/goods of the enterprise

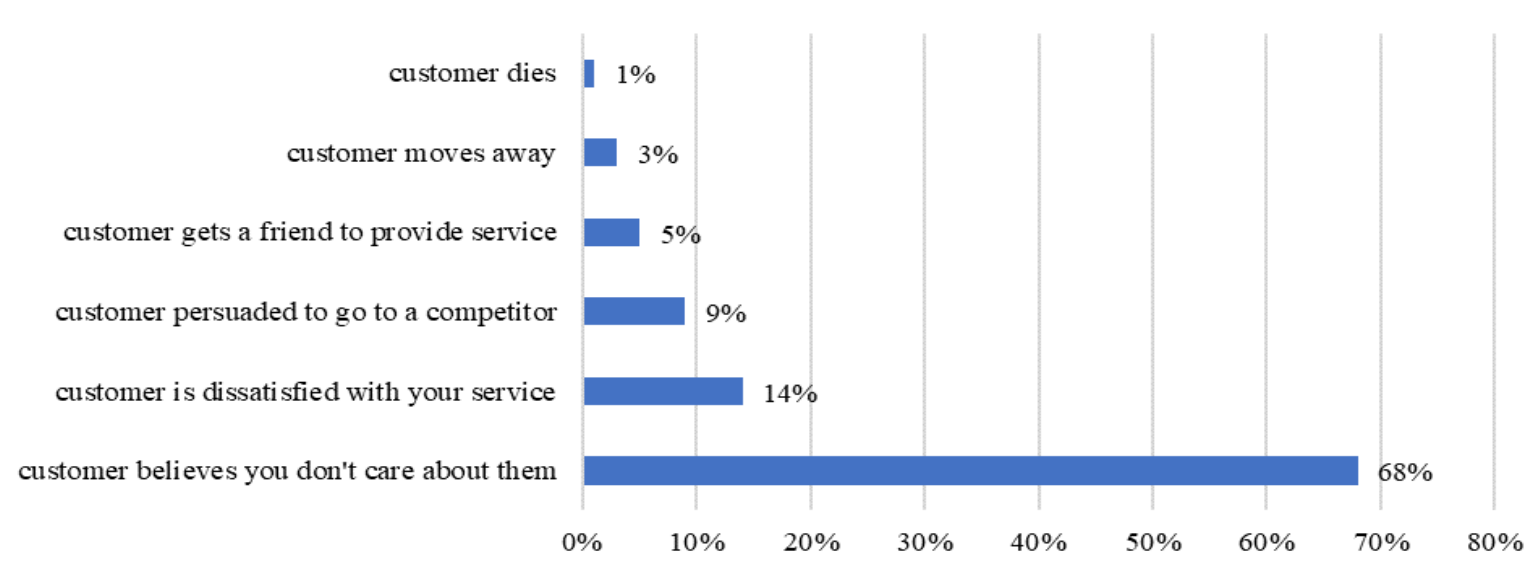

(source: compiled by the authors based on [13])

As you can see, the main reason for the loss of loyalty to the company is not the quality of its goods, the price of competitors, but the attitude towards the client himself [13-14]. This factor must be taken into account in modern conditions when developing a marketing strategy for the financial growth of an enterprise.

\section{Methodology.}

Studies have shown that the development of a marketing strategy for an enterprise is carried out according to almost the same scheme (Fig. 4.). However, the study showed that customers had changed dramatically: first of all, they are interested in a personal attitude, and only then in the quality of goods, price - the usual indicators that have always been in the first places.

Thus, we believe that the main goal of a marketing strategy for an enterprise's financial growth is to ensure customer loyalty, i.e. customer focus.

\section{Results.}

As noted above, the algorithm for developing a marketing strategy is approximately the same (Fig. 4), and we will take it as a basis, but the tools and indicators used have a qualitatively different character.

As noted above, the algorithm for developing a marketing strategy is approximately the same (Fig. 4), and we will take it as a basis. Still, the tools and indicators used are qualitatively different.

Loyalty can be described as a two-dimensional construct that includes both a special emotional attitude and repeat purchases (Fig. 6).

According to the relationship between behavioural loyalty and loyalty based on relationships, Dick and Basu divide all consumers into 4 categories.

The first category is consumers without loyalty - a low level of emotional attitudes and rare repeat purchases. 
Figure 6. Types of consumers according to the Dick and Basu model

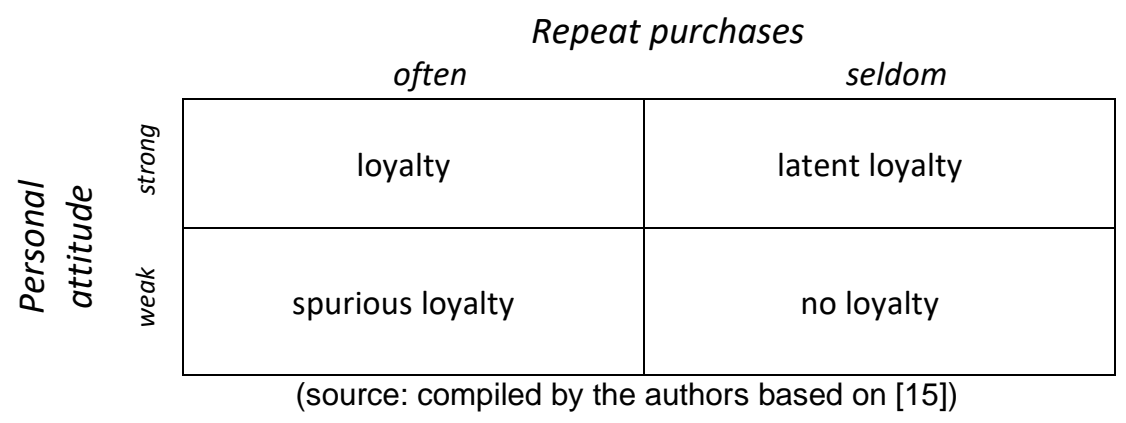

Spurious (fake) loyalty is characterized by low levels of emotional liking and high repeat purchases.

Latent loyalty implies a high level of emotional sympathy and a low level of repeat purchases.

Figure 7. Enhanced Marketing Strategy Development Process

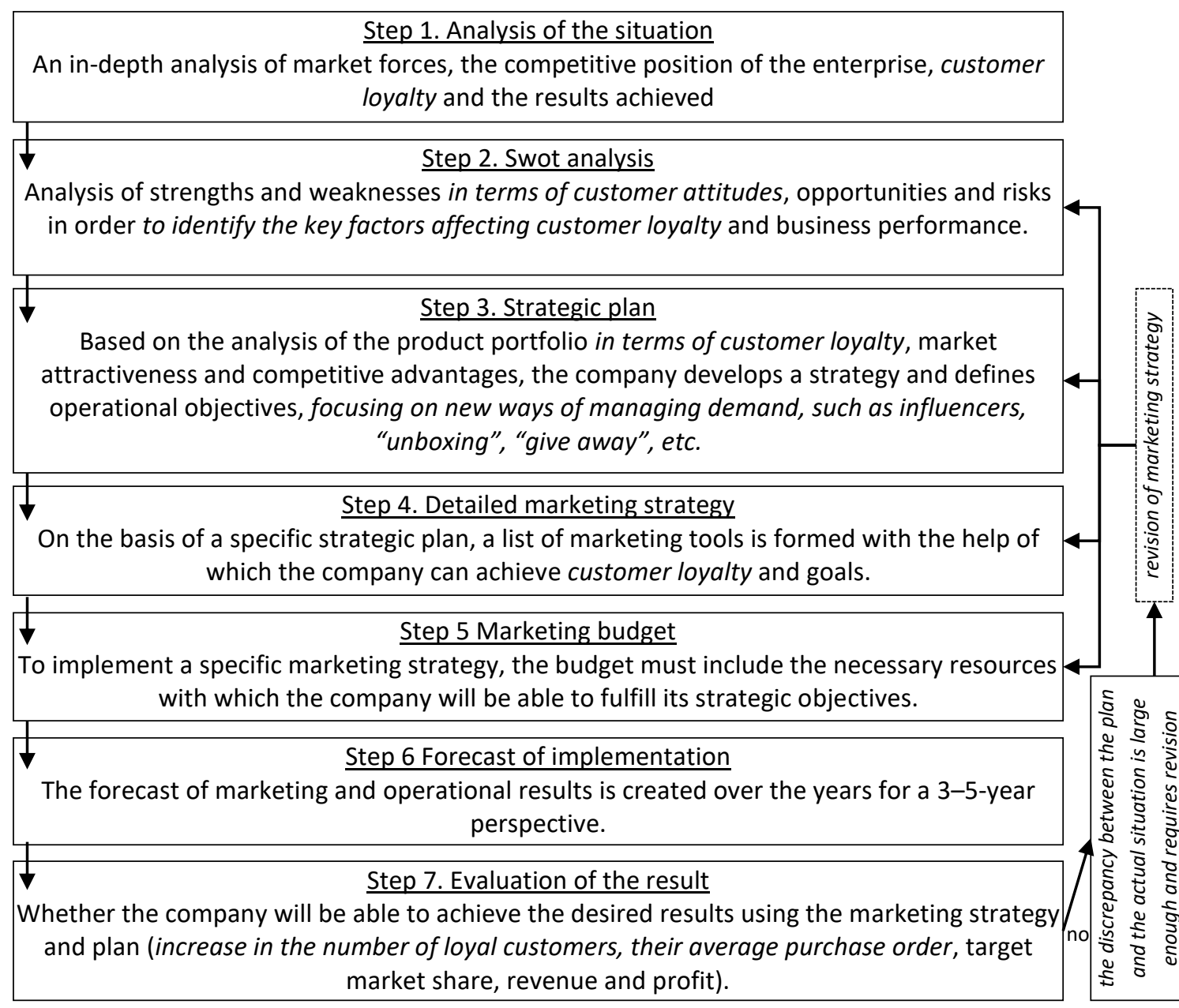

(Source: contributed by the authors)

True customer loyalty to a company or product is the most preferred type of loyalty and represents a favourable relationship between consumer emotion and repeat purchases. However, consumers who show true loyalty are the easiest to retain. That said, maintaining existing standards may be sufficient.

Therefore, when developing a marketing strategy, an enterprise should focus on groups 2 and 3.

The following factors can be identified that prevent customers from moving from groups 2 and 3 to group 4:

- acquaintance with the products/services of the company happened recently; 
- low involvement can be caused by the dynamics of the development of a certain market. While most competing brands look the same, customers may not always be able to tell them apart;

- the consumer does not see the difference between brands, makes a purchase by inertia, which maintains his loyalty to this brand/enterprise based on habituation.

By identifying the causes, you can develop ways to manage them to increase customer loyalty.

Improving Fig. 4, we will present a client-oriented algorithm for developing a marketing strategy for an enterprise's financial growth (Fig. 7).

A marketing strategy based on customer focus can achieve the following results:

1) stimulating sales and improving key indicators (income, profit, market share):

a) an increase in the size of the average purchase;

b) cross-selling and sales of more expensive goods/services;

c) attracting new customers, increasing the customer database;

2) improving the characteristics of the brand (improving the attitude to the enterprise, brand):

a) the formation of emotional attachment to the enterprise or product;

b) informing the target audience, groups of influence;

c) improving marketing communications (direct communication instead of the enterprise-mediaclient model);

3) meeting other needs of the enterprise:

a) increasing the attractiveness of the enterprise for business partners: by establishing a direct communication channel with the audience, the company will be able to offer business partners more than competitors;

b) the ability to conduct fast and inexpensive marketing research among consumers.

\section{Experiment and discussion.}

Due to the limited volume of the article, we will provide a fragment of testing the tool that is used in the algorithm (Step 3), namely the result of "unpacking" the influencers. In 2020, The Game company (Kiev) approached influencers with a proposal to promote products through Facebook, which was for people to shoot a video about how they unpack and use the company's products. In total, 3 people took part:

1 person - a well-known blogger (Kyiv) with an audience of 500+ thousand subscribers;

2 person - TV presenter (Kyiv) with an audience of 50+ thousand subscribers;

3 person - a beginner blogger (Odesa) with an audience of 200+ thousand subscribers.

Each influencer provided his audience with a unique discount code, so we can say with $100 \%$ certainty who triggered the purchase. The results are presented in Table 2.

It should be noted that all activities were valid for a month: there was not a single order after this deadline.

According to the results of the company's work with influencers in 2020, the following features can be noted:

- this demand management tool is not suitable for all types of goods;

- Influencer 2 (TV presenter) was the least effective. This is due to the fact that, firstly, it has the smallest audience and is not targeted, and secondly, the commercial was online for only a day.

- Influencer 3 (beginner blogger) was the most effective. Even though his audience is 2.5 times smaller than that of the famous blogger, he presented the product more emotionally; the video was filmed not at home (like in 1), but in different beautiful places (a cafe, a park and a restaurant decorated themed for a holiday); 
- Effectiveness of Influencer 3 was different: the first "unpacking" of the product was the most effective, the thematic "unpacking" of the product was no less effective. Presentation of the goods a month after the first did not give any result, because the audience did not have time to grow much, but it is worth noting repeated orders, i.e. this tool is suitable not only for product presentation but also for increasing customer loyalty.

Table 2. Results of cooperation of the enterprise with influencers in 2020

\begin{tabular}{|c|c|}
\hline Period & Influencer/number of orders \\
\hline \multicolumn{2}{|r|}{ Person 1. Unpacked the product and told in detail about the properties. } \\
\hline 1 week & 17 orders ( 2 on the first day) \\
\hline 2 week & 7 orders \\
\hline month & 2 orders \\
\hline Total & 28 orders \\
\hline \multicolumn{2}{|r|}{ Person 2. In the story (24 hours action) presented the product as a gift and briefly told what she liked } \\
\hline 1 week & 2 orders \\
\hline 2 week & 0 \\
\hline month & 0 \\
\hline Total & 2 orders \\
\hline \multicolumn{2}{|r|}{ Person 3.} \\
\hline \multicolumn{2}{|r|}{ 1) Unpacked the goods, spoke in detail and emotionally about the properties. } \\
\hline 1 week & 10 orders ( 7 in the first 2 days) \\
\hline 2 week & 7 orders \\
\hline month & 2 orders \\
\hline Total & 28 orders \\
\hline \multicolumn{2}{|r|}{ 2) Re-unpacking after a month. } \\
\hline 1 week & 7 ( 3 customers re-ordered). \\
\hline 2 week & 0 \\
\hline month & 0 \\
\hline Total & 7 orders \\
\hline \multicolumn{2}{|r|}{ 3) Unpacking 10 days before the holiday - presentation of the thematic product. } \\
\hline 1 week & 18 orders \\
\hline 2 week & 22 orders \\
\hline month & 0 \\
\hline Total & 20 orders \\
\hline \multicolumn{2}{|r|}{ Sale of similar goods by enterprises for the same period } \\
\hline Total & 25 orders \\
\hline
\end{tabular}

It should be noted that this tool is one of the cheapest because the costs of the enterprise are: 1 ) the cost of the donated sample of goods; 2 ) the discount provided to buyers; 3 )\% of the sale to the influencer. If there were no sales at all, then the enterprise's financial losses would consist only in the cost of 1 product. Thus, we consider this modern tool to be effective.

\section{Conclusions.}

Consumer behaviour is a complex process based on various factors that have social, economic, psychological and personal roots. Analysis and management of the formation of consumer behaviour are the basis for the effectiveness of using marketing tools, as part of the implementation of the company's global strategy. Social communications are a critical factor that determines both the formation of relationships between the company and consumers and a tool that allows you to modify consumer behaviour. The correct application of social interactions, coupled with traditional marketing mechanisms, can have a powerful synergistic effect that can shape consumers' necessary perception, those aspects that the company wants to focus on. 


\section{References}

1. English, J. (2020). Marketing strategy. in book: How to Organise \& Operate a Small Business in Australia. DOI: 10.4324/9781003116028-17

2. Shpak, N., Kulyniak, I., Gvozd, M., Malynovska, Y., \& Sroka, W. (2020). Estimation of the marketing activity of banking structures, Acta Universitatis Agriculturae et Silviculturae Mendelianae Brunensis, 68(1), 229-242.

3. Varadarajan, R. Strategic marketing, marketing strategy and market strategy. Academy of Marketing Science Review, 5(3-4), 78-90, 2015. DOI: 10.1007/s13162-015-0073-9

4. Kendyukhov, A.V., \& Faivishenko, D.S. (2012). Assessing brand management efficiency basing on benchmarking, Actual Problems of Economics, 137(11), 131-137.

5. Best, R. J. (2012). Market-Based Management. Pearson; 6th edition.

6. Kotler., Ph.T. (2015). Principles of Marketing Pearson; 16th edition.

7. Kim, W. Ch., \& Mauborgne, R. (2015). Blue Ocean Strategy, Expanded Edition: How to Create Uncontested Market Space and Make the Competition Irrelevant, Harvard Business Review Press; Revised ed. edition.

8. Wind, Y., Douglas, S.P., \& Perlmutter, H. V. (1973). Guidelines for Developing International Marketing Strategies. Journal of Marketing, 37(2), 14-23. DOI: 10.1177/002224297303700205

9. Daniels, M., \& Loveless, C. (2007). Chapter 23 - developing a marketing strategy, in book: Wedding Planning and Management, Butterworth-Heinemann. DOI: 10.1016/B978-0-7506-8233-6.500329.

10.Kerr, H. (1974). Developing a Marketing Strategy. Cornell Hotel and Restaurant Administration Quarterly, 15(3), 34-42,. DOI: 10.1177/001088047401500307

11.Chukhray, N.I., \& Kulyniak, I.Y. (2015). Marketing research on Lviv region enterprises readiness to entering EU markets. Actual Problems of Economics, 173(11), 77-86, 2015.

12.Dligach, A. (2017). Development of marketing strategies in system-reflexive marketing. Technology Audit and Production Reserves, 5/4(37), 34-40. DOI: 10.15587/23128372.2017.113120

13.Hjelm, S. (2020). Good customer service yields customer loyalty, Online available from https://www.superoffice.com/blog/good-customer-service-yields-customer-loyalty/.

14.Koraus, A., Stefko, R., \& Dobrovic, J. (2016). Decision-making satisfaction and behaviour of bank customers: Survey results analysis. Actual Problems of Economics, 186(12), 291-301.

15.Dick, A.S., \& Basu, K. (1994). Customer loyalty: Toward an integrated conceptual framework. JAMS 22, 99-113. DOI: 10.1177/0092070394222001 